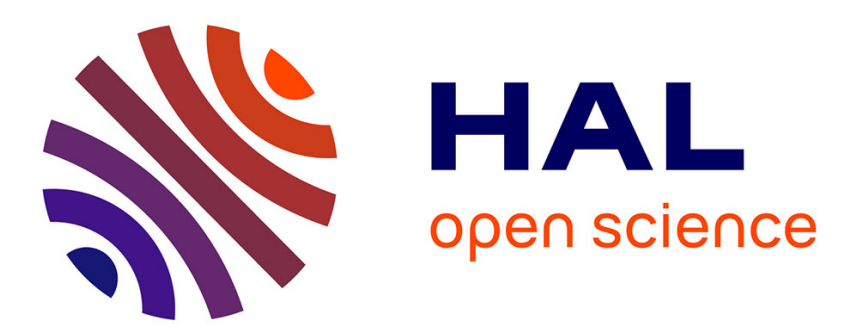

\title{
Neuronal specification in C. elegans: combining lineage inheritance with intercellular signaling
}

\author{
Antoine Barrière, Vincent Bertrand
}

\section{To cite this version:}

Antoine Barrière, Vincent Bertrand. Neuronal specification in C. elegans: combining lineage inheritance with intercellular signaling. Journal of Neurogenetics, In press, 10.1080/01677063.2020.1781850 . hal-02908275

\section{HAL Id: hal-02908275 \\ https://hal.science/hal-02908275}

Submitted on 28 Jul 2020

HAL is a multi-disciplinary open access archive for the deposit and dissemination of scientific research documents, whether they are published or not. The documents may come from teaching and research institutions in France or abroad, or from public or private research centers.
L'archive ouverte pluridisciplinaire HAL, est destinée au dépôt et à la diffusion de documents scientifiques de niveau recherche, publiés ou non, émanant des établissements d'enseignement et de recherche français ou étrangers, des laboratoires publics ou privés. 
Neuronal specification in $C$. elegans: combining lineage inheritance with intercellular signaling

Antoine Barrière and Vincent Bertrand

Aix Marseille Univ, CNRS, IBDM, Turing Center for Living Systems, Marseille, France

Contact:

Antoine Barrière, antoine.barriere@univ-amu.fr, ORCID: 0000-0001-8566-417X

Vincent Bertrand, vincent.bertrand@univ-amu.fr, ORCID: 0000-0002-9036-2544

Institut de Biologie du Développement de Marseille, Campus de Luminy, Case 907, 13288 Marseille cedex 09, France 


\title{
Neuronal specification in $C$. elegans: combining lineage inheritance with intercellular signaling
}

\begin{abstract}
The nervous system is composed of a high diversity of neuronal types. How this diversity is generated during development is a key question in neurobiology. Addressing this question is one of the reasons that led Sydney Brenner to develop the nematode C. elegans as a model organism. While there was initially a debate on whether the neuronal specification follows a 'European' model (determined by ancestry) or an 'American' model (determined by intercellular communication), several decades of research have established that the truth lies somewhere in between. Neurons are specified by the combination of transcription factors inherited from the ancestor cells and signaling between neighboring cells (especially Wnt and Notch signaling). This converges to the activation in newly generated postmitotic neurons of a specific set of terminal selector transcription factors that initiate and maintain the differentiation of the neuron. In this review we also discuss the evolution of these specification mechanisms in other nematodes and beyond.
\end{abstract}

Keywords: neuronal specification, transcriptional regulation, Wnt signaling, C. elegans 


\section{Introduction}

Bilaterian animals can display very sophisticated behaviors, mirrored by the cellular complexity of their nervous system that is composed by a high diversity of neuronal types. A major subject in neurobiology is to understand the origin of this diversity during development. This question was of great interest to Sydney Brenner and was one of the reasons why he chose to develop the nematode C. elegans as a model organism (Brenner, 1974). C. elegans indeed presents several advantages for the study of nervous system development. Its nervous system is relatively simple with only 302 neurons in the adult hermaphrodite (White, Southgate, Thomson, \& Brenner, 1986). The animal is transparent, allowing researchers to follow nervous system development directly in vivo with single cell resolution. Finally, the life cycle is short ( 3 days at $25^{\circ} \mathrm{C}$ ) and the brood size is large, making C. elegans a great system to identify genes involved in nervous system development via genetic screens.

The establishment of the lineage of $C$. elegans by John Sulston and colleagues showed that neurons are produced by an invariant series of cell divisions (Sulston and Horvitz, 1977; Sulston, Schierenberg, White, \& Thomson, 1983). There was a debate among early C. elegans researchers as to whether the fate of a neuron is established in a 'European' way or 'American' way (Brown, 2003). In a 'European' model the identity of a neuron is determined by the ancestry of the cell in a vertical manner, while in an 'American' model it is determined by the cellular environment in an horizontal manner.

In this review, we discuss the molecular and cellular mechanisms at the basis of

neuronal specification in $C$. elegans showing that neurons are generated via a combination of lineage inheritance (vertical) and intercellular signaling (horizontal). We then present how terminal selector transcription factors trigger neuronal differentiation and maintain the differentiated state of neurons following specification. Finally, we discuss to what extent these neuronal specification programs are conserved in other nematodes and beyond.

\section{Neuronal specification: a combination of lineage inheritance and intercellular signaling}

In C. elegans, the majority of neurons is generated during embryogenesis by series of asymmetric divisions oriented along the anteroposterior axis (Sulston, et al., 1983). Many transcription factors that affect neuronal cell fate specification have been identified, via 
forward genetic screens or reverse RNAi screens (reviewed in (Hobert, 2010)). Analysis of their expression patterns suggests that, during development, a neuronal precursor goes through a series of transient regulatory states defined by the expression of different combinations of transcription factors (see for example (Bertrand and Hobert, 2009; Poole, Bashllari, Cochella, Flowers, \& Hobert, 2011; Sarafi-Reinach, Melkman, Hobert, \& Sengupta, 2001)). These observations have been recently generalized using single-cell RNA sequencing of most embryonic cells (Packer et al., 2019), showing that following each division of a neuronal progenitor, the two daughter cells acquire transcription profiles different from each other and from their mother cell.

This transition from one regulatory state to another is triggered by the asymmetric division process. In $C$. elegans, the $\mathrm{Wnt} / \beta$-catenin asymmetry pathway (a specialized $\mathrm{Wnt} / \beta$-catenin pathway) controls asymmetric divisions oriented along the anteroposterior axis (reviewed in (Bertrand, 2016; Phillips and Kimble, 2009; Sawa and Korswagen, 2013)). This pathway regulates many asymmetric divisions in the early embryo (Kaletta, Schnabel, \& Schnabel, 1997; Lin, Hill, \& Priess, 1998) and also controls the terminal asymmetric divisions of neuronal progenitors during neurulation (epidermal enclosure) (Figure 1A) (Bertrand and Hobert, 2009; P. M. Gordon and Hobert, 2015; Murgan et al., 2015). The Wnt/ $\beta$-catenin asymmetry pathway controls the expression of target genes in the daughter cells via the TCF transcription factor POP-1 and its transcriptional coactivator SYS-1, a $\beta$-catenin (Kidd, Miskowski, Siegfried, Sawa, \& Kimble, 2005; Lin, et al., 1998; Lin, Thompson, \& Priess, 1995; Phillips, Kidd, King, Hardin, \& Kimble, 2007). The pathway modulates the activity of POP-1 and SYS-1 by regulating the nuclear export of POP-1 (Lo, Gay, Odom, Shi, \& Lin, 2004; Rocheleau et al., 1999) and the degradation of SYS-1 (Huang, Shetty, Robertson, \& Lin, 2007; Phillips, et al., 2007). Following asymmetric division, high levels of SYS-1 relative to POP-1 in the posterior nucleus lead to the formation of a POP-1:SYS-1 complex that activates transcription (Huang, et al., 2007; Kidd, et al., 2005; Phillips, et al., 2007). In the anterior nucleus, SYS-1 levels are low and POP-1 mostly free of SYS-1 represses transcription.

Studies of cis-regulatory regions have established how the lineage history (transcription factors inherited from the mother cell) and the asymmetric division cue (Wnt/ $\beta$-catenin asymmetry pathway) are integrated to generate novel regulatory states in the daughter cells. For example, in the larval neuroectodermal T lineage, the Hox transcription factor NOB-1 and 
the $\mathrm{Pbx}$ transcription factor $\mathrm{CEH}-20$ are inherited from the mother cell and cooperate with the POP-1:SYS-1 complex in the posterior daughter to activate the expression of the Meis transcription factor gene $p s a-3$ by directly binding to its cis-regulatory regions (Arata et al., 2006). Similarly, in the AIY neuron lineage of the embryo, the LIM-homeodomain transcription factor TTX-3, inherited from the mother cell (SMDD/AIY mother), cooperates with POP-1:SYS-1 to induce the transcription of the homeodomain gene ceh-10 only in the posterior daughter (AIY neuron), by binding to its cis-regulatory regions (Bertrand and Hobert, 2009) (Figure 1B, division generating the SMDD and AIY neurons). While direct target genes activated in the posterior daughter cell contain POP-1 binding sites and are activated by the POP-1:SYS-1 complex, genes activated in the anterior daughter are not regulated via POP-1 binding sites. For example, in the AIY neuron lineage of the embryo, it has been observed that POP-1, in the absence of SYS-1, activates the expression of an anterior target genes $t t x-3$ by forming a complex with another transcription factor protein REF-2 (a Zic factor) and binding to a REF-2 binding site in the ttx-3 cis-regulatory regions (Murgan, et al., 2015) (Figure 1B, division generating the SMDD/AIY mother and the SIAD/SIBV mother). Whether POP-1 activates transcription in a similar manner in anterior daughters of other neuronal lineages remains to be established. These data illustrate how combining lineage ancestry (via inherited transcription factors) with intercellular signaling (via the asymmetric Wnt pathway) generates neuronal type diversity in the nervous system of C. elegans (Figure 1A). Secreted Wnt ligands can play an instructive role in the asymmetric divisions regulated by the $\mathrm{Wnt} / \beta$-catenin asymmetry pathway. For example, it has been established that for the endomesoderm precursor cell EMS or the larval blast cell T, Wnt ligands, secreted from a posterior source, control the division orientation and the asymmetry of daughter cell fates (Goldstein, Takeshita, Mizumoto, \& Sawa, 2006). Interestingly, it has been recently observed that three Wnt ligands (CWN-1, CWN-2 and MOM-2), coming from the posterior of the embryo, regulate in an instructive manner the terminal asymmetric divisions of embryonic neuronal progenitors (Kaur et al., 2020). This illustrates the importance of intercellular signaling during neuronal development in C. elegans.

Another intercellular signaling pathway playing an important role in neuronal cell fate specification in C. elegans is the Notch pathway. This pathway is involved in the generation of left-right asymmetries in the nervous system. While the nervous system of C. elegans is essentially bilateral symmetric, some neuronal left-right pairs, which are symmetric at the morphological level, display some functional and molecular asymmetries (Hobert, Johnston, 
\& Chang, 2002). In the case of the pair of ASE taste neurons, the left and right cells express different sets of chemoreceptors that allow sensing different chemicals (Pierce-Shimomura, Faumont, Gaston, Pearson, \& Lockery, 2001; Yu, Avery, Baude, \& Garbers, 1997). The difference between left and right ASE is induced in the very early embryo (four-cell stage) by a Notch signal, coming from the posterior P lineage, which represses the expression of the Tbox transcription factor genes $t b x-37$ and $t b x-38$ in the blastomere $\mathrm{ABp}$, giving rise to the right $\mathrm{ASE}$, but not in the blastomere $\mathrm{ABa}$, giving rise to the left ASE (Poole and Hobert, 2006). Another example is the pairs of AIY interneurons and SMDD, SIAD and SIBV motor neurons, which act in a circuit controlling navigation behavior downstream of ASE. In these neurons, the bHLH gene hlh-16 is expressed in a left-right asymmetric manner and is important for their correct axonal projections (Bertrand, Bisso, Poole, \& Hobert, 2011). This asymmetry is established independently of the ASE asymmetry by a later Notch signal (during gastrulation) coming from the left mesoderm, which increases $h l h-16$ expression on the left side. Another example of left-right asymmetry is the pair of AWC olfactory neurons: the odorant receptor gene str-2 is activated in only one of the two AWC neurons in a stochastic manner with no left-right bias. Communication between the two AWC neurons, involving calcium signaling but not Notch, ensures that only one AWC expresses str-2 (Troemel, Sagasti, \& Bargmann, 1999).

To conclude, neuronal cell fate specification in C. elegans involves both lineage transmission (inherited transcription factors) and intercellular signaling (such as Wnt or Notch). It therefore follows neither a pure 'European' nor a pure ‘American' model, but is instead a mix of both.

\section{Neuronal differentiation: initiation and maintenance of terminal neuronal fate by terminal selectors}

The function of a neuron relies on the specific set of terminal differentiation genes (or effector genes) that it expresses such as neurotransmitter receptors, ion channels or neurotransmitter synthesis pathway genes. In the C. elegans nervous system, the expression of many neuron type-specific terminal differentiation genes has been mapped. For example the cholinergic, GABAergic or glutamatergic neurons have been systematically identified (Gendrel, Atlas, \& Hobert, 2016; Pereira et al., 2015; Serrano-Saiz et al., 2013). For several neuron types, the analysis of cis-regulatory regions of their specific terminal differentiation genes have revealed 
that they are often regulated by a common set of transcription factors, called terminal selectors (Hobert, 2008). These transcription factors also frequently autoregulate their expression, therefore maintaining the type identity of the neuron throughout the life of the animal. One example is the cholinergic interneuron AIY where the homeodomain transcription factors TTX-3 and CEH-10 directly activate and maintain the expression of a large battery of terminal differentiation genes: the choline acetyltransferase cha-1, the acetylcholine vesicular transporter unc-17, the neurotransmitter receptors ser-2, gar-2 and mod-1, etc. (Figure 2) (Wenick and Hobert, 2004). Other examples of terminal selectors include the two homeodomain transcription factors MEC-3 and UNC-86 in touch receptor neurons (Zhang et al., 2002), the zinc finger transcription factor CHE-1 in the taste neuron ASE (Etchberger et al., 2007) or the COE transcription factor UNC-3 in cholinergic motorneurons (Kratsios, Stolfi, Levine, \& Hobert, 2011). In addition, many other transcription factors controlling the expression of terminal differentiation genes in various neuronal types have been identified (for a comprehensive review see (Hobert, 2016)).

The connection between these terminal differentiation programs and earlier cell fate specification events, such as asymmetric divisions, has been less characterized. The link has been elucidated in the case of the cholinergic interneuron AIY (Figure 2) (Bertrand and Hobert, 2009; Murgan, et al., 2015): the expression of the AIY terminal selector genes $t$ tx-3 and ceh-10 is set up in the early postmitotic AIY neuron by two types of transient developmental inputs. One is the specific transcription factors inherited from the lineage history: proneural bHLH factors (HLH-3, HLH-16), their binding partner HLH-2 and the Zic transcription factor REF-2. The other input is the Wnt/ $\beta$-catenin asymmetry pathway, which regulates the terminal asymmetric divisions in the AIY lineage. These lineage specific transcription factors and the Wnt/ $\beta$-catenin asymmetry pathway are directly integrated at the level of the cis-regulatory regions of $t$ tx-3 and ceh-10 to establish their coexpression specifically in the early AIY neurons. The lineage specific transcription factors (HLH-3, HLH-16, HLH-2 and REF-2) and the Wnt pathway effectors (POP-1 and SYS-1) subsequently disappear from the AIY neuron, and TTX-3 and CEH-10 expression is then maintained via a positive autoregulatory loop, where they directly bind their own cisregulatory regions and positively regulate their expression. In the postmitotic AIY neuron, TTX-3 and CEH-10 directly activate and maintain the expression of a large battery of terminal differentiation genes, therefore determining the type-specific function of the AIY neuron. This illustrates how terminal selector transcription factors can connect early 
specification events to the terminal differentiation of the neuron. Whether a similar regulatory logic applies for the activation of other terminal selectors remains to be established.

\section{Evolution of neuronal specification programs in nematodes}

Neuronal determination mechanisms based on lineage and cell neighborhood could constrain neuronal development and affect its flexibility and evolvability. Indeed, there was, early on, an impression of very high conservation of the nervous system across the vast phylogenetic distances of nematodes. In one of the seminal papers by John Sulston and Sydney Brenner, it was noted that: ' The nervous system of the nematode Ascaris lumbricoides appears to be very similar to that of $C$. elegans. The homology of the catecholaminergic neurons lends support to the possibility that, notwithstanding their great disparity in size, there is a strong conservation of the properties of the nervous system between these two nematodes ' (Sulston, Dew, \& Brenner, 1975). It is indeed tempting to try to assign almost one-to-one correspondence of the 302 C. elegans neurons (Sulston and Horvitz, 1977; Sulston, et al., 1983) to the 298 neurons found in Ascaris (Stretton et al., 1992). But this apparent morphological conservation could underlie pervasive functional divergence. Due to the difficulty of duplicating genetic screens performed in C. elegans in other nematode species, there has been limited number of experiments analyzing the evolution of neuronal specification mechanisms. Overall, studies suggest that the neuroanatomy of nematodes is not as highly conserved as previously described (Han, Boas, \& Schroeder, 2015) (Figure 3A), although the ability to assign single-cell homology across great evolutionary distances is a critical factor to assess conservation and variation in neuronal fates.

\section{Variations in neuroanatomy and lineage}

Gross neuroanatomical comparisons across many nematode species, most not amenable to manipulation, revealed extensive variability in number and time of birth of ventral nerve cord neurons and dye-filling sensory neurons across multiple clades (Han, et al., 2015). Finer analyses, comparing individual neurons between C. elegans and Pristionchus pacificus by serial electron microscopy, in the paryngeal (Bumbarger, Riebesell, Rodelsperger, \& Sommer, 2013) and olfactory (Hong et al., 2019) nervous systems, found remarkable conservation of 
neuron homology, as defined by cell body position and neurite anatomy, but also extensive rewiring and changes in fate, e.g. from interneuron to motor neuron.

Embryonic lineages were established for other species in the Caenorhabditis genus, namely $C$. briggsae (Zhao et al., 2008), C. remanei and C. brenneri (Memar et al., 2019). For these three species, embryonic development until the start of muscle contraction is identical, but for some small variations in the timing of division, and one cell escaping programmed cell death to become part of the pharynx in C. briggsae and C. remanei (Memar, et al., 2019). Accordingly, the number and identity of neurons appear to be perfectly conserved in the species investigated. However, once comparisons reach outside the Caenorhabditis genus, like with the marine nematode Pellioditis marina (Houthoofd et al., 2003), developmental differences become apparent: while cell divisions maintain a strong homology (95.5\%), final fate is less well conserved; only $85 \%$ of cells acquiring a neuronal fate in $P$. marina are also neurons in $C$. elegans. The difference is made up by cells acquiring pharyngeal, epidermal or programmed cell death fates, for a final count of 194 neurons at muscle contraction compared with 244 in C. elegans. In the more distantly related nematode Romanomermis culicivorax (Schulze and Schierenberg, 2009), the lineage is more generally divergent, and early development proceeds in a more monoclonal fashion. Cell positions are also markedly different, with neuronal precursors arranged as rings around the embryo, suggesting possible changes in cell-cell interactions.

\section{Variations in neurotransmitter identity patterns}

One of the first tools used to compare the nervous system across species is the Falck-Hillarp method, where formaldehyde reacts with catecholamines to form fluorophores. Using this method, John Sulston (Sulston, et al., 1975) compared dopamine neurons between the yet to be described $C$. elegans nervous system and Ascaris lumbricoides, and identified strong similarities between the two species in the head and body, but noted the presence of a pair of dopaminergic neurons in the $A$. lumbricoides tail without equivalent in $C$. elegans. A later study, looking at dopaminergic neurons in rhabditid nematodes, including the Caenorhabditis genus, found perfect conservation of pattern and easy assignation of one-to-one orthology (Rivard et al., 2010). This constant pattern of dopaminergic neurons, although striking, might give an impression of almost perfect conservation. However, in the more distant specie Haemonchus contortus, dopamine was not detected in head neurons, but only in commissures 
(Rao, Forrester, Keller, \& Prichard, 2011) suggesting a diverging pattern of dopaminergic neurons.

Similar studies targeting serotonergic neurons reveal that they are also highly conserved within the Caenorhabditis genus; however, in more distantly related species, only the serotonergic NSM neurons were found to be consistently conserved (Rivard, et al., 2010), including with Ascaris suum (Johnson, Reinitz, Sithigorngul, \& Stretton, 1996) and $H$. contortus (Rao, et al., 2011). Finally, some GABAergic neurons were found to be so well conserved between $C$. elegans and A. suum, that clear homologs were identified for the four RMEs and DVB (Guastella, Johnson, \& Stretton, 1991), and for DDs and VDs in the ventral nerve cord (Johnson and Stretton, 1987); however, three pairs of head neurons found in $A$. suum have no clear homologs in C. elegans (Guastella, et al., 1991).

Taken together these data reveal that, while neuronal types seem relatively well conserved in the Caenorhabditis genus, there are important variations at greater evolutionary distances.

\section{Variations in transcriptional regulation}

The variations in neuronal cell fates observed between nematodes suggest that the transcriptional mechanisms that specify neuronal identity have changed. In addition, even if neuronal types are conserved, the detailed transcriptional regulation of their identity may have evolved. These variations can happen at the level of the trans-acting factors, such as transcription factors or miRNA, and at the level of cis-regulatory regions (Figure 3B). Strikingly, several trans regulators of neuronal fate were found to vary across nematode species. The miRNA $l s y$ - 6 , triggering the left-right asymmetry of ASE neurons in C. elegans, is absent from the genome of $P$. pacificus (Ahmed et al., 2013). The transcription factor che-1 involved in specifying ASE fate and restricted to that cell pair in C. elegans, is expressed in an additional pair of neurons, homolog of ASG, in P. pacificus (Hong, et al., 2019). For the nuclear receptor $o d r-7$, involved in specifying AWA neuron cilia and expressed exclusively in that neuron in C. elegans, the P. pacificus ortholog is expressed in the homologs of AWC and ADF neurons, but not in the homolog of AWA (Hong, et al., 2019). The downstream terminal differentiation gene $o d r-3$ (a G-protein subunit) also diverged extensively in its expression compared with C. elegans (Hong, et al., 2019). 
In addition to variations at the level of transcription factors, changes are also observed at the level of cis-regulatory elements. One tool of choice to study cis-regulatory changes between $C$. elegans and C. briggsae, which have one-to-one neuron homology, is to swap transcriptional reporters between species (K. L. Gordon and Ruvinsky, 2012) (Figure 3B). If the regulatory mechanisms are conserved, the expression pattern would stay the same; if changes happened in cis-regulatory elements or in trans factors, the expression patterns driven by the reporters would vary. For example, in C. elegans, the transcription factor CEH-6 regulates lin-11 expression in the interneuron RIC by binding to an intronic enhancer; in C. briggsae, the endogenous lin-11 enhancer fails to drive expression in RIC, while reciprocal promoter swaps do drive expression in RIC (Amon and Gupta, 2017). Interestingly, an independent comparative RNAi screen found evidence for functional divergence of the CEH-6 transcription factor between C. elegans and C. briggsae (Verster, Ramani, McKay, \& Fraser, 2014). This illustrates one example of functional divergence both in cis and in trans in the transcriptional regulation of neuronal fate. Over the years, different teams have performed promoter swaps for multiple genes, including some genes involved in regulation of neuronal fates. While for some genes like the transcription factors ceh-24 (Harfe and Fire, 1998), pag-3 (Aamodt et al., 2000), mec-3 (Xue, Finney, Ruvkun, \& Chalfie, 1992), and odr-7 (Colosimo, Tran, \& Sengupta, 2003) the regulatory mechanisms appear to be conserved between $C$. elegans and C. briggsae, they diverged for others: regulation of the chemoreceptor srsx-3 and of its putative transcription factor lim-4 diverged between C. elegans and C. briggsae (Nokes et al., 2009); the C. briggsae promoter of gcy-5, a chemoreceptor, does not drive expression in ASE neurons while its C. elegans ortholog does (Etchberger, Flowers, Poole, Bashllari, \& Hobert, 2009); and the C. briggsae promoter of another chemoreceptor odr-10 lacks a repressive UNC-3 binding site present in its C. elegans ortholog, and drives expression in one extra neuron pair (Kim, Colosimo, Yeung, \& Sengupta, 2005). A detailed study of the promoter of the vesicular GABA transporter $u n c-47$ also revealed compensatory coevolution of cis and trans regulatory factors between C. elegans and C. briggsae (Barriere, Gordon, \& Ruvinsky, 2012). More generally, this trend of cryptic changes in transcriptional regulation was found to be pervasive, when testing multiple neuronal genes from several Caenorhabditis species in the C. elegans trans-regulatory context (Barriere and Ruvinsky, 2014). Even though the final expression pattern of many genes may be conserved within Caenorhabditis nematodes, in accordance with conservation of fine anatomy and neurotransmitter neuronal fates, these promoter swaps reveal extensive developmental systems drift (True and Haag, 2001): while purifying selection maintains the final phenotype, the molecular mechanisms 
underlying its specification are less constrained and are able to diverge, provided that the output stays constant. Cis-regulatory elements diverged over time, but coevolved with their upstream transcription factors to maintain their outputs.

In conclusions, several scenarios of transcriptional evolution between $C$. elegans and $C$. briggsae are observed (Figure 3B): conservation of transcription factors and cis-regulatory elements (e.g. ceh-24); coevolution of trans-acting factors and cis-regulatory elements to maintain the final expression pattern (e.g. unc-47); and changes in regulatory mechanisms inducing variations in the final expression pattern (e.g. lin-11).

\section{Beyond nematodes}

Cis-regulatory elements involved in neuronal specification are usually not conserved over greater evolutionary distances, between phyla (Ruvinsky and Ruvkun, 2003). However, some degree of functional conservation can be observed at the level of the transcription factors that regulate neuronal cell fate acquisition. For example, proneural bHLH transcription factors (such as Achaete-scute or NeuroD family members) that play an important role in the early steps of neuronal specification in C. elegans (Frank, Baum, \& Garriga, 2003; Hallam, Singer, Waring, \& Jin, 2000; Krause et al., 1997; Murgan, et al., 2015; Poole, et al., 2011), are also at the top of the hierarchy in the neuronal determination process in other animals (Baker and Brown, 2018). Conservation is also found at downstream steps. For example, in C. elegans, the dopamine pathway genes are activated by the Ets transcription factor AST-1 and the homeodomain transcription factor CEH-43 (Doitsidou et al., 2013; Flames and Hobert, 2009), a role conserved in mice where their orthologs, Etv1 and Dlx2, are activators of the dopaminergic fate, specifically in the olfactory bulb. In addition, it has been recently observed that the Zic transcription factor REF-2 represses dopaminergic fate in C. elegans, a function conserved in the mouse where Zic1 and Zic2 repress the dopaminergic phenotype in the olfactory bulb (Tiveron et al., 2017). Another interesting example is the role of COE transcription factors in cholinergic motor neuron differentiation. In $C$. elegans, the COE transcription factor UNC-3 regulates the expression of many terminal differentiation genes of cholinergic motor neurons including the cholinergic gene battery (Kratsios, et al., 2011). This role is conserved in the ascidian Ciona intestinalis, where the sole COE transcription factor controls the cholinergic fate of motor neurons (Kratsios, et al., 2011). However, while the $\mathrm{COE}$ transcription factor Ebf2 also regulates some aspects of axial motor neuron development 
in mice, it does not control their cholinergic fate (Catela et al., 2019), suggesting both conservation and divergence in $\mathrm{COE}$ transcription factor functions. Some degree of conservation can also be observed over long evolutionary distances at cellular and signaling level. For example asymmetric divisions are widely used in diverse metazoans to generate neuronal diversity (Hartenstein and Stollewerk, 2015). In addition, the Wnt pathway, which controls neuronal progenitors asymmetric divisions in C. elegans, also plays a role in the regulation of neural stem cells asymmetric divisions in the mouse cortex (Chenn and Walsh, 2002; Delaunay, Cortay, Patti, Knoblauch, \& Dehay, 2014; Kalani et al., 2008; Woodhead, Mutch, Olson, \& Chenn, 2006).

\section{Conclusions}

Since the seminal works of Sydney Brenner and John Sulston, decades of studies of nervous system development in C. elegans have established that neuronal diversity is generated via the combinations of two types of information: lineage history (carried by inherited transcription factors) and intercellular signaling (especially Wnt and Notch signaling). Neuronal specification in C. elegans is therefore a mix between the lineage-based 'European' way and the interaction-based 'American' way. This information is integrated at the level of terminal selector transcription factors that activate and maintain the expression of large batteries of terminal differentiation genes in postmitotic neurons, and are therefore responsible for the acquisition and maintenance of neuronal type identities. While neuronal types are relatively well conserved within Caenorhabditis nematodes, there is more variability in distant nematodes. The evolution of neuronal specification involves changes at both the cisregulatory element and trans-acting factor levels. However, some aspects of neuronal specification mechanisms are also conserved over large evolutionary distances. There is no doubt that, in the future, studies of nematodes, which offer an amazing level of cellular and molecular resolutions, will continue to deepen our knowledge of the mechanisms at the basis of nervous system development and evolution.

\section{Acknowledgments}


This revue is part of a series of articles commemorating the contributions of Sydney Brenner and John Sulston to neuroscience. Work in our laboratory is funded by the Agence Nationale de la Recherche (ANR-14-CE11-0001, ANR-11-LABX-0054 and ANR-17-ERC2-0018) and the Fondation pour la Recherche Médicale (DEQ20180339160).

\section{Disclosure of interest}

The authors report no conflict of interest.

\section{Figure legends}

Figure 1 . Generation of neuronal diversity by the combination of lineage history and $\mathrm{Wnt} / \beta$ catenin asymmetry.

(A) Following each asymmetric division the Wnt/ $\beta$-catenin asymmetry pathway cooperates with transcription factors (TF) inherited from the mother cell to activate the expression of different transcription factors in the anterior and posterior daughter cells. (B) Example of the AIY neuron lineage (ABpl/rpapaa lineage). In the first cell division, the POP-1 protein interacts with the REF-2 protein to activate the transcription of the $t t x-3$ gene in the anterior daughter (SMDD/AIY mother) via a REF-2 binding site present in the $t$ tx -3 promoter. This activation is blocked by SYS-1 in the posterior daughter (SIAD/SIBV mother). In the second cell division, the TTX-3 protein and the POP-1:SYS-1 complex activate the transcription of the ceh-10 gene in the posterior daughter (AIY neuron) via TTX-3 and POP-1 binding sites present in the ceh-10 promoter. In the anterior daughter (SMDD neuron), POP-1 without SYS-1 represses ceh-10 expression.

Figure 2. Connection of early specification events to the terminal differentiation program in the AIY interneuron.

During embryonic development transient developmental inputs (lineage specific transcription factors and the $\mathrm{Wnt} / \beta$-catenin asymmetry pathway) initiate the expression of the terminal transcription factors TTX-3 and CEH-10 in the AIY lineage. TTX-3 and CEH-10 subsequently maintain their expression and activate a large battery of type specific terminal differentiation genes. 
Figure 3. Conservation and divergence of neurodevelopment in nematodes.

(A) Phylogeny of species discussed in this review, showing conservation or divergence of cell lineage or neurotransmitter cellular patterns, compared with C. elegans, at different phylogenetic distances. (B) Possible scenarios of transcriptional evolution. If a transcription factor and its target cis-regulatory element are conserved between C. elegans and C. briggsae, there is no change in regulation and no difference in expression pattern is observed when the C. briggsae cis-regulatory element is placed in the C. elegans trans-regulatory environment. If there was coevolution between trans-regulatory factors and cis-regulatory elements, the $C$. briggsae cis-regulatory element placed in the C. elegans trans-regulatory environment will give an altered expression pattern. Finally, if there was a change in transcription factors binding to a cis-regulatory element, the regulation might be completely lost when the $C$. briggsae cis-regulatory element is placed in the C. elegans trans-regulatory environment.

\section{References}

Aamodt, E., Shen, L., Marra, M., Schein, J., Rose, B., \& McDermott, J. B. (2000). Conservation of sequence and function of the pag-3 genes from C. elegans and C. briggsae. Gene, 243(1-2), pp. 67-74. doi:10.1016/s0378-1119(99)00560-0 Retrieved from https://www.ncbi.nlm.nih.gov/pubmed/10675614

Ahmed, R., Chang, Z., Younis, A. E., Langnick, C., Li, N., Chen, W., . . Dieterich, C. (2013). Conserved miRNAs are candidate post-transcriptional regulators of developmental arrest in free-living and parasitic nematodes. Genome Biol Evol, 5(7), pp. 1246-1260. doi:10.1093/gbe/evt086 Retrieved from https://www.ncbi.nlm.nih.gov/pubmed/23729632

Amon, S., \& Gupta, B. P. (2017). Intron-specific patterns of divergence of lin-11 regulatory function in the C. elegans nervous system. Dev Biol, 424(1), pp. 90-103. doi:10.1016/j.ydbio.2017.02.005 Retrieved from https://www.ncbi.nlm.nih.gov/pubmed/28215941

Arata, Y., Kouike, H., Zhang, Y., Herman, M. A., Okano, H., \& Sawa, H. (2006). Wnt signaling and a Hox protein cooperatively regulate psa-3/Meis to determine daughter cell fate after asymmetric cell division in C. elegans. Dev Cell, 11(1), pp. 105-115. doi:S15345807(06)00253-X [pii] 10.1016/j.devcel.2006.04.020 Retrieved from http://www.ncbi.nlm.nih.gov/entrez/query.fcgi? $\mathrm{cmd}=$ Retrieve $\& \mathrm{db}=\mathrm{PubMed} \& \mathrm{dopt}=\mathrm{Citation} \&$ list uids $=16824957$ 
Baker, N. E., \& Brown, N. L. (2018). All in the family: proneural bHLH genes and neuronal diversity. Development, 145(9)doi:10.1242/dev.159426 Retrieved from https://www.ncbi.nlm.nih.gov/pubmed/29720483

Barriere, A., Gordon, K. L., \& Ruvinsky, I. (2012). Coevolution within and between regulatory loci can preserve promoter function despite evolutionary rate acceleration. PLoS Genet, 8(9), p e1002961. doi:10.1371/journal.pgen.1002961 Retrieved from https://www.ncbi.nlm.nih.gov/pubmed/23028368

Barriere, A., \& Ruvinsky, I. (2014). Pervasive divergence of transcriptional gene regulation in Caenorhabditis nematodes. PLoS Genet, 10(6), p e1004435.

doi:10.1371/journal.pgen.1004435 Retrieved from

https://www.ncbi.nlm.nih.gov/pubmed/24968346

Bertrand, V. (2016). beta-catenin-driven binary cell fate decisions in animal development. Wiley Interdiscip Rev Dev Biol, 5(3), pp. 377-388. doi:10.1002/wdev.228 Retrieved from https://www.ncbi.nlm.nih.gov/pubmed/26952169

Bertrand, V., Bisso, P., Poole, R. J., \& Hobert, O. (2011). Notch-dependent induction of left/right asymmetry in C. elegans interneurons and motoneurons. Curr Biol, 21(14), pp. 1225-1231. doi:S0960-9822(11)00661-0 [pii]

10.1016/j.cub.2011.06.016 Retrieved from http://www.ncbi.nlm.nih.gov/entrez/query.fcgi? $\mathrm{cmd}=$ Retrieve $\& \mathrm{db}=\mathrm{PubMed} \& d o p t=C i t a t i o n \&$ list uids $=21737278$

Bertrand, V., \& Hobert, O. (2009). Linking asymmetric cell division to the terminal differentiation program of postmitotic neurons in C. elegans. Dev Cell, 16(4), pp. 563-575. doi:S1534-5807(09)00085-9 [pii]

10.1016/j.devcel.2009.02.011 Retrieved from

http://www.ncbi.nlm.nih.gov/entrez/query.fcgi? $\mathrm{cmd}=$ Retrieve $\& \mathrm{db}=\mathrm{PubMed} \& d o p t=C i t a t i o n \&$ list uids $=19386265$

Brenner, S. (1974). The genetics of Caenorhabditis elegans. Genetics, 77(1), pp. 71-94. Retrieved from https://www.ncbi.nlm.nih.gov/pubmed/4366476

Brown, A. (2003). In the beginning was the worm: Columbia University Press.

Bumbarger, D. J., Riebesell, M., Rodelsperger, C., \& Sommer, R. J. (2013). System-wide rewiring underlies behavioral differences in predatory and bacterial-feeding nematodes. Cell, 152(1-2), pp. 109-119. doi:10.1016/j.cell.2012.12.013 Retrieved from https://www.ncbi.nlm.nih.gov/pubmed/23332749

Catela, C., Correa, E., Wen, K., Aburas, J., Croci, L., Consalez, G. G., \& Kratsios, P. (2019). An ancient role for collier/Olf/Ebf (COE)-type transcription factors in axial motor neuron development. Neural Dev, 14(1), p 2. doi:10.1186/s13064-018-0125-6 Retrieved from https://www.ncbi.nlm.nih.gov/pubmed/30658714 
Chenn, A., \& Walsh, C. A. (2002). Regulation of cerebral cortical size by control of cell cycle exit in neural precursors. Science, 297(5580), pp. 365-369. doi:10.1126/science.1074192 Retrieved from http://www.ncbi.nlm.nih.gov/pubmed/12130776

Colosimo, M. E., Tran, S., \& Sengupta, P. (2003). The divergent orphan nuclear receptor ODR-7 regulates olfactory neuron gene expression via multiple mechanisms in Caenorhabditis elegans. Genetics, 165(4), pp. 1779-1791. Retrieved from https://www.ncbi.nlm.nih.gov/pubmed/14704165

Delaunay, D., Cortay, V., Patti, D., Knoblauch, K., \& Dehay, C. (2014). Mitotic spindle asymmetry: a Wnt/PCP-regulated mechanism generating asymmetrical division in cortical precursors. Cell Rep, 6(2), pp. 400-414. doi:10.1016/j.celrep.2013.12.026 Retrieved from http://www.ncbi.nlm.nih.gov/pubmed/24412369

Doitsidou, M., Flames, N., Topalidou, I., Abe, N., Felton, T., Remesal, L., . . Hobert, O. (2013). A combinatorial regulatory signature controls terminal differentiation of the dopaminergic nervous system in C. elegans. Genes Dev, 27(12), pp. 1391-1405. doi:10.1101/gad.217224.113 Retrieved from https://www.ncbi.nlm.nih.gov/pubmed/23788625

Etchberger, J. F., Flowers, E. B., Poole, R. J., Bashllari, E., \& Hobert, O. (2009). Cisregulatory mechanisms of left/right asymmetric neuron-subtype specification in C. elegans. Development, 136(1), pp. 147-160. doi:10.1242/dev.030064 Retrieved from https://www.ncbi.nlm.nih.gov/pubmed/19060335

Etchberger, J. F., Lorch, A., Sleumer, M. C., Zapf, R., Jones, S. J., Marra, M. A., . . Hobert, O. (2007). The molecular signature and cis-regulatory architecture of a C. elegans gustatory neuron. Genes Dev, 21(13), pp. 1653-1674. doi:10.1101/gad.1560107 Retrieved from https://www.ncbi.nlm.nih.gov/pubmed/17606643

Flames, N., \& Hobert, O. (2009). Gene regulatory logic of dopamine neuron differentiation. Nature, 458(7240), pp. 885-889. doi:10.1038/nature07929 Retrieved from https://www.ncbi.nlm.nih.gov/pubmed/19287374

Frank, C. A., Baum, P. D., \& Garriga, G. (2003). HLH-14 is a C. elegans achaete-scute protein that promotes neurogenesis through asymmetric cell division. Development, 130(26), pp. 6507-6518. doi:10.1242/dev.00894 Retrieved from https://www.ncbi.nlm.nih.gov/pubmed/14627726

Gendrel, M., Atlas, E. G., \& Hobert, O. (2016). A cellular and regulatory map of the GABAergic nervous system of C. elegans. Elife, 5doi:10.7554/eLife.17686 Retrieved from https://www.ncbi.nlm.nih.gov/pubmed/27740909

Goldstein, B., Takeshita, H., Mizumoto, K., \& Sawa, H. (2006). Wnt signals can function as positional cues in establishing cell polarity. Dev Cell, 10(3), pp. 391-396. doi:S15345807(06)00008-6 [pii] 
10.1016/j.devcel.2005.12.016 Retrieved from

http://www.ncbi.nlm.nih.gov/entrez/query.fcgi? $\mathrm{cmd}=$ Retrieve \& $\mathrm{db}=\mathrm{PubMed} \& d o p t=C i t a t i o n \&$ list uids $=16516841$

Gordon, K. L., \& Ruvinsky, I. (2012). Tempo and mode in evolution of transcriptional regulation. PLoS Genet, 8(1), p e1002432. doi:10.1371/journal.pgen.1002432 Retrieved from https://www.ncbi.nlm.nih.gov/pubmed/22291600

Gordon, P. M., \& Hobert, O. (2015). A competition mechanism for a homeotic neuron identity transformation in C. elegans. Dev Cell, 34(2), pp. 206-219. doi:10.1016/j.devcel.2015.04.023 Retrieved from https://www.ncbi.nlm.nih.gov/pubmed/26096732

Guastella, J., Johnson, C. D., \& Stretton, A. O. (1991). GABA-immunoreactive neurons in the nematode Ascaris. J Comp Neurol, 307(4), pp. 584-597. doi:10.1002/cne.903070406 Retrieved from https://www.ncbi.nlm.nih.gov/pubmed/1869633

Hallam, S., Singer, E., Waring, D., \& Jin, Y. (2000). The C. elegans NeuroD homolog cnd-1 functions in multiple aspects of motor neuron fate specification. Development, 127(19), pp. 4239-4252. Retrieved from https://www.ncbi.nlm.nih.gov/pubmed/10976055

Han, Z., Boas, S., \& Schroeder, N. E. (2015). Unexpected Variation in Neuroanatomy among Diverse Nematode Species. Front Neuroanat, 9, p 162. doi:10.3389/fnana.2015.00162 Retrieved from https://www.ncbi.nlm.nih.gov/pubmed/26778973

Harfe, B. D., \& Fire, A. (1998). Muscle and nerve-specific regulation of a novel NK-2 class homeodomain factor in Caenorhabditis elegans. Development, 125(3), pp. 421-429. Retrieved from https://www.ncbi.nlm.nih.gov/pubmed/9425137

Hartenstein, V., \& Stollewerk, A. (2015). The evolution of early neurogenesis. Dev Cell, 32(4), pp. 390-407. doi:10.1016/j.devcel.2015.02.004 Retrieved from https://www.ncbi.nlm.nih.gov/pubmed/25710527

Hobert, O. (2008). Regulatory logic of neuronal diversity: terminal selector genes and selector motifs. Proc Natl Acad Sci U S A, 105(51), pp. 20067-20071. doi:0806070105 [pii] 10.1073/pnas.0806070105 Retrieved from http://www.ncbi.nlm.nih.gov/entrez/query.fcgi? $\mathrm{cmd}=$ Retrieve \&db=PubMed\&dopt=Citation\& $\underline{\text { list uids }=19104055}$

Hobert, O. (2010). Neurogenesis in the nematode Caenorhabditis elegans. WormBook, pp. 124. doi:10.1895/wormbook.1.12.2 Retrieved from https://www.ncbi.nlm.nih.gov/pubmed/20891032

Hobert, O. (2016). A map of terminal regulators of neuronal identity in Caenorhabditis elegans. Wiley Interdiscip Rev Dev Biol, 5(4), pp. 474-498. doi:10.1002/wdev.233 Retrieved from https://www.ncbi.nlm.nih.gov/pubmed/27136279 
Hobert, O., Johnston, R. J., Jr., \& Chang, S. (2002). Left-right asymmetry in the nervous system: the Caenorhabditis elegans model. Nat Rev Neurosci, 3(8), pp. 629-640.

doi:10.1038/nrn897

nrn897 [pii] Retrieved from

http://www.ncbi.nlm.nih.gov/entrez/query.fcgi? $\mathrm{cmd}=$ Retrieve $\& \mathrm{db}=$ PubMed\&dopt=Citation $\&$ $\underline{\text { list uids }=12154364}$

Hong, R. L., Riebesell, M., Bumbarger, D. J., Cook, S. J., Carstensen, H. R., Sarpolaki, T., . . . Sommer, R. J. (2019). Evolution of neuronal anatomy and circuitry in two highly divergent nematode species. Elife, 8doi:10.7554/eLife.47155 Retrieved from

https://www.ncbi.nlm.nih.gov/pubmed/31526477

Houthoofd, W., Jacobsen, K., Mertens, C., Vangestel, S., Coomans, A., \& Borgonie, G. (2003). Embryonic cell lineage of the marine nematode Pellioditis marina. Dev Biol, 258(1), pp. 57-69. doi:10.1016/s0012-1606(03)00101-5 Retrieved from https://www.ncbi.nlm.nih.gov/pubmed/12781682

Huang, S., Shetty, P., Robertson, S. M., \& Lin, R. (2007). Binary cell fate specification during C. elegans embryogenesis driven by reiterated reciprocal asymmetry of TCF POP-1 and its coactivator beta-catenin SYS-1. Development, 134(14), pp. 2685-2695. doi:dev.008268 [pii] 10.1242/dev.008268 Retrieved from http://www.ncbi.nlm.nih.gov/entrez/query.fcgi? $\mathrm{cmd}=$ Retrieve $\& \mathrm{db}=$ PubMed\&dopt=Citation \& list uids $=17567664$

Johnson, C. D., Reinitz, C. A., Sithigorngul, P., \& Stretton, A. O. (1996). Neuronal localization of serotonin in the nematode Ascaris suum. J Comp Neurol, 367(3), pp. 352-360. doi:10.1002/(SICI)1096-9861(19960408)367:3<352::AID-CNE3>3.0.CO;2-4 Retrieved from https://www.ncbi.nlm.nih.gov/pubmed/8698897

Johnson, C. D., \& Stretton, A. O. (1987). GABA-immunoreactivity in inhibitory motor neurons of the nematode Ascaris. J Neurosci, 7(1), pp. 223-235. Retrieved from https://www.ncbi.nlm.nih.gov/pubmed/3543249

Kalani, M. Y., Cheshier, S. H., Cord, B. J., Bababeygy, S. R., Vogel, H., Weissman, I. L., . . . Nusse, R. (2008). Wnt-mediated self-renewal of neural stem/progenitor cells. Proc Natl Acad Sci US A, 105(44), pp. 16970-16975. doi:10.1073/pnas.0808616105 Retrieved from http://www.ncbi.nlm.nih.gov/pubmed/18957545

Kaletta, T., Schnabel, H., \& Schnabel, R. (1997). Binary specification of the embryonic lineage in Caenorhabditis elegans. Nature, 390(6657), pp. 294-298. doi:10.1038/36869 Retrieved from

http://www.ncbi.nlm.nih.gov/entrez/query.fcgi? $\mathrm{cmd}=$ Retrieve $\& \mathrm{db}=$ PubMed\&dopt=Citation \& list_uids $=9384382$

Kaur, S., Melenec, P., Murgan, S., Bordet, G., Recouvreux, P., Lenne, P. F., \& Bertrand, V. (2020). Wnt ligands regulate the asymmetric divisions of neuronal progenitors in C. elegans embryos. Development, 147(7)doi:10.1242/dev.183186 Retrieved from https://www.ncbi.nlm.nih.gov/pubmed/32156756 
Kidd, A. R., 3rd, Miskowski, J. A., Siegfried, K. R., Sawa, H., \& Kimble, J. (2005). A betacatenin identified by functional rather than sequence criteria and its role in Wnt/MAPK signaling. Cell, 121(5), pp. 761-772. doi:S0092-8674(05)00339-9 [pii]

10.1016/j.cell.2005.03.029 Retrieved from

http://www.ncbi.nlm.nih.gov/entrez/query.fcgi? $\mathrm{cmd}=$ Retrieve $\& \mathrm{db}=$ PubMed\&dopt $=$ Citation \& $\underline{\text { list uids }=15935762}$

Kim, K., Colosimo, M. E., Yeung, H., \& Sengupta, P. (2005). The UNC-3 Olf/EBF protein represses alternate neuronal programs to specify chemosensory neuron identity. Dev Biol, 286(1), pp. 136-148. doi:10.1016/j.ydbio.2005.07.024 Retrieved from https://www.ncbi.nlm.nih.gov/pubmed/16143323

Kratsios, P., Stolfi, A., Levine, M., \& Hobert, O. (2011). Coordinated regulation of cholinergic motor neuron traits through a conserved terminal selector gene. Nat Neurosci, 15(2), pp. 205-214. doi:nn.2989 [pii]

10.1038/nn.2989 Retrieved from

http://www.ncbi.nlm.nih.gov/entrez/query.fcgi? $\mathrm{cmd}=$ Retrieve \&db=PubMed\&dopt=Citation \& list_uids $=22119902$

Krause, M., Park, M., Zhang, J. M., Yuan, J., Harfe, B., Xu, S. Q., . . Fire, A. (1997). A C. elegans E/Daughterless bHLH protein marks neuronal but not striated muscle development. Development, 124(11), pp. 2179-2189. Retrieved from http://www.ncbi.nlm.nih.gov/entrez/query.fcgi? $\mathrm{cmd}=$ Retrieve $\& \mathrm{db}=\mathrm{PubMed} \& \mathrm{dopt}=\mathrm{Citation} \&$ list_uids $=9187144$

Lin, R., Hill, R. J., \& Priess, J. R. (1998). POP-1 and anterior-posterior fate decisions in C. elegans embryos. Cell, 92(2), pp. 229-239. doi:S0092-8674(00)80917-4 [pii] Retrieved from http://www.ncbi.nlm.nih.gov/entrez/query.fcgi? $\mathrm{cmd}=$ Retrieve $\& \mathrm{db}=\mathrm{PubMed} \& \mathrm{dopt}=\mathrm{Citation} \&$ list uids $=9458047$

Lin, R., Thompson, S., \& Priess, J. R. (1995). pop-1 encodes an HMG box protein required for the specification of a mesoderm precursor in early C. elegans embryos. Cell, 83(4), pp. 599-609. doi:0092-8674(95)90100-0 [pii] Retrieved from

http://www.ncbi.nlm.nih.gov/entrez/query.fcgi? $\mathrm{cmd}=$ Retrieve $\& \mathrm{db}=\mathrm{PubMed} \& \mathrm{dopt}=\mathrm{Citation} \&$ list uids $=7585963$

Lo, M. C., Gay, F., Odom, R., Shi, Y., \& Lin, R. (2004). Phosphorylation by the betacatenin/MAPK complex promotes 14-3-3-mediated nuclear export of TCF/POP-1 in signalresponsive cells in C. elegans. Cell, 117(1), pp. 95-106. Retrieved from http://www.ncbi.nlm.nih.gov/pubmed/15066285

Memar, N., Schiemann, S., Hennig, C., Findeis, D., Conradt, B., \& Schnabel, R. (2019). Twenty million years of evolution: The embryogenesis of four Caenorhabditis species are indistinguishable despite extensive genome divergence. Dev Biol, 447(2), pp. 182-199. doi:10.1016/j.ydbio.2018.12.022 Retrieved from https://www.ncbi.nlm.nih.gov/pubmed/30590018 
Murgan, S., Kari, W., Rothbacher, U., Iche-Torres, M., Melenec, P., Hobert, O., \& Bertrand, V. (2015). Atypical Transcriptional Activation by TCF via a Zic Transcription Factor in C. elegans Neuronal Precursors. Dev Cell, 33(6), pp. 737-745. doi:10.1016/j.devcel.2015.04.018 Retrieved from http://www.ncbi.nlm.nih.gov/pubmed/26073017

Nokes, E. B., Van Der Linden, A. M., Winslow, C., Mukhopadhyay, S., Ma, K., \& Sengupta, P. (2009). Cis-regulatory mechanisms of gene expression in an olfactory neuron type in Caenorhabditis elegans. Dev Dyn, 238(12), pp. 3080-3092. doi:10.1002/dvdy.22147

Retrieved from https://www.ncbi.nlm.nih.gov/pubmed/19924784

Packer, J. S., Zhu, Q., Huynh, C., Sivaramakrishnan, P., Preston, E., Dueck, H., . . Murray, J. I. (2019). A lineage-resolved molecular atlas of C. elegans embryogenesis at single-cell resolution. Science, 365(6459)doi:10.1126/science.aax1971 Retrieved from https://www.ncbi.nlm.nih.gov/pubmed/31488706

Pereira, L., Kratsios, P., Serrano-Saiz, E., Sheftel, H., Mayo, A. E., Hall, D. H., . . Hobert, O. (2015). A cellular and regulatory map of the cholinergic nervous system of C. elegans. Elife, 4doi:10.7554/eLife.12432 Retrieved from https://www.ncbi.nlm.nih.gov/pubmed/26705699

Phillips, B. T., Kidd, A. R., 3rd, King, R., Hardin, J., \& Kimble, J. (2007). Reciprocal asymmetry of SYS-1/beta-catenin and POP-1/TCF controls asymmetric divisions in Caenorhabditis elegans. Proc Natl Acad Sci U S A, 104(9), pp. 3231-3236. doi:0611507104 [pii]

10.1073/pnas.0611507104 Retrieved from

http://www.ncbi.nlm.nih.gov/entrez/query.fcgi? $\mathrm{cmd}=$ Retrieve $\& \mathrm{db}=\mathrm{PubMed} \& d o p t=C i t a t i o n \&$ list uids=17296929

Phillips, B. T., \& Kimble, J. (2009). A new look at TCF and beta-catenin through the lens of a divergent C. elegans Wnt pathway. Dev Cell, 17(1), pp. 27-34. doi:S1534-5807(09)00258-5 [pii] 10.1016/j.devcel.2009.07.002 Retrieved from http://www.ncbi.nlm.nih.gov/entrez/query.fcgi? $\mathrm{cmd}=$ Retrieve $\& \mathrm{db}=$ PubMed\&dopt=Citation $\&$ list_uids=19619489

Pierce-Shimomura, J. T., Faumont, S., Gaston, M. R., Pearson, B. J., \& Lockery, S. R. (2001). The homeobox gene lim-6 is required for distinct chemosensory representations in C. elegans. Nature, 410(6829), pp. 694-698. doi:10.1038/35070575 Retrieved from https://www.ncbi.nlm.nih.gov/pubmed/11287956

Poole, R. J., Bashllari, E., Cochella, L., Flowers, E. B., \& Hobert, O. (2011). A Genome-Wide RNAi Screen for Factors Involved in Neuronal Specification in Caenorhabditis elegans. PLoS Genet, 7(6), p e1002109. doi:10.1371/journal.pgen.1002109 Retrieved from https://www.ncbi.nlm.nih.gov/pubmed/21698137

Poole, R. J., \& Hobert, O. (2006). Early embryonic programming of neuronal left/right asymmetry in C. elegans. Curr Biol, 16(23), pp. 2279-2292. doi:S0960-9822(06)02266-4 [pii] 
10.1016/j.cub.2006.09.041 Retrieved from

http://www.ncbi.nlm.nih.gov/entrez/query.fcgi? $\mathrm{cmd}=$ Retrieve \&db=PubMed\&dopt=Citation\& list_uids $=17141609$

Rao, V. T., Forrester, S. G., Keller, K., \& Prichard, R. K. (2011). Localisation of serotonin and dopamine in Haemonchus contortus. Int J Parasitol, 41(2), pp. 249-254.

doi:10.1016/j.ijpara.2010.09.002 Retrieved from

https://www.ncbi.nlm.nih.gov/pubmed/20887725

Rivard, L., Srinivasan, J., Stone, A., Ochoa, S., Sternberg, P. W., \& Loer, C. M. (2010). A comparison of experience-dependent locomotory behaviors and biogenic amine neurons in nematode relatives of Caenorhabditis elegans. BMC Neurosci, 11, p 22. doi:10.1186/14712202-11-22 Retrieved from https://www.ncbi.nlm.nih.gov/pubmed/20167133

Rocheleau, C. E., Yasuda, J., Shin, T. H., Lin, R., Sawa, H., Okano, H., . . Mello, C. C. (1999). WRM-1 activates the LIT-1 protein kinase to transduce anterior/posterior polarity signals in C. elegans. Cell, 97(6), pp. 717-726. Retrieved from http://www.ncbi.nlm.nih.gov/pubmed/10380924

Ruvinsky, I., \& Ruvkun, G. (2003). Functional tests of enhancer conservation between distantly related species. Development, 130(21), pp. 5133-5142. doi:10.1242/dev.00711 Retrieved from https://www.ncbi.nlm.nih.gov/pubmed/12944426

Sarafi-Reinach, T. R., Melkman, T., Hobert, O., \& Sengupta, P. (2001). The lin-11 LIM homeobox gene specifies olfactory and chemosensory neuron fates in C. elegans.

Development, 128(17), pp. 3269-3281. Retrieved from

https://www.ncbi.nlm.nih.gov/pubmed/11546744

Sawa, H., \& Korswagen, H. C. (2013). Wnt signaling in C. elegans. WormBook, pp. 1-30. doi:10.1895/wormbook.1.7.2 Retrieved from http://www.ncbi.nlm.nih.gov/pubmed/25263666

Schulze, J., \& Schierenberg, E. (2009). Embryogenesis of Romanomermis culicivorax: an alternative way to construct a nematode. Dev Biol, 334(1), pp. 10-21.

doi:10.1016/j.ydbio.2009.06.009 Retrieved from

https://www.ncbi.nlm.nih.gov/pubmed/19523940

Serrano-Saiz, E., Poole, R. J., Felton, T., Zhang, F., De La Cruz, E. D., \& Hobert, O. (2013). Modular control of glutamatergic neuronal identity in C. elegans by distinct homeodomain proteins. Cell, 155(3), pp. 659-673. doi:10.1016/j.cell.2013.09.052 Retrieved from https://www.ncbi.nlm.nih.gov/pubmed/24243022

Stretton, A., Donmoyer, J., Davis, R., Meade, J., Cowden, C., \& Sithigorngul, P. (1992). Motor behavior and motor nervous system function in the nematode Ascaris suum. $J$ Parasitol, 78(2), pp. 206-214. Retrieved from https://www.ncbi.nlm.nih.gov/pubmed/1556637 
Sulston, J. E., Dew, M., \& Brenner, S. (1975). Dopaminergic neurons in the nematode Caenorhabditis elegans. J Comp Neurol, 163(2), pp. 215-226. doi:10.1002/cne.901630207 Retrieved from https://www.ncbi.nlm.nih.gov/pubmed/240872

Sulston, J. E., \& Horvitz, H. R. (1977). Post-embryonic cell lineages of the nematode, Caenorhabditis elegans. Dev Biol, 56(1), pp. 110-156. Retrieved from http://www.ncbi.nlm.nih.gov/pubmed/838129

Sulston, J. E., Schierenberg, E., White, J. G., \& Thomson, J. N. (1983). The embryonic cell lineage of the nematode Caenorhabditis elegans. Dev Biol, 100(1), pp. 64-119. doi:00121606(83)90201-4 [pii] Retrieved from

http://www.ncbi.nlm.nih.gov/entrez/query.fcgi? $\mathrm{cmd}=$ Retrieve $\& \mathrm{db}=\mathrm{PubMed} \& \mathrm{dopt}=\mathrm{Citation} \&$ list uids $=6684600$

Tiveron, M. C., Beclin, C., Murgan, S., Wild, S., Angelova, A., Marc, J., . . Cremer, H. (2017). Zic-Proteins Are Repressors of Dopaminergic Forebrain Fate in Mice and C. elegans. J Neurosci, 37(44), pp. 10611-10623. doi:10.1523/JNEUROSCI.3888-16.2017 Retrieved from https://www.ncbi.nlm.nih.gov/pubmed/28972122

Troemel, E. R., Sagasti, A., \& Bargmann, C. I. (1999). Lateral signaling mediated by axon contact and calcium entry regulates asymmetric odorant receptor expression in C. elegans. Cell, 99(4), pp. 387-398. doi:S0092-8674(00)81525-1 [pii] Retrieved from http://www.ncbi.nlm.nih.gov/entrez/query.fcgi? $\mathrm{cmd}=$ Retrieve \&db=PubMed\&dopt=Citation\& list uids $=10571181$

True, J. R., \& Haag, E. S. (2001). Developmental system drift and flexibility in evolutionary trajectories. Evol Dev, 3(2), pp. 109-119. doi:10.1046/j.1525-142x.2001.003002109.x Retrieved from https://www.ncbi.nlm.nih.gov/pubmed/11341673

Verster, A. J., Ramani, A. K., McKay, S. J., \& Fraser, A. G. (2014). Comparative RNAi screens in C. elegans and C. briggsae reveal the impact of developmental system drift on gene function. PLoS Genet, 10(2), p e1004077. doi:10.1371/journal.pgen.1004077 Retrieved from https://www.ncbi.nlm.nih.gov/pubmed/24516395

Wenick, A. S., \& Hobert, O. (2004). Genomic cis-regulatory architecture and trans-acting regulators of a single interneuron-specific gene battery in C. elegans. Dev Cell, 6(6), pp. 757770. doi:10.1016/j.devcel.2004.05.004

S1534580704001650 [pii] Retrieved from http://www.ncbi.nlm.nih.gov/entrez/query.fcgi? $\mathrm{cmd}=$ Retrieve $\& \mathrm{db}=\mathrm{PubMed} \& d o p t=C i t a t i o n \&$ list_uids $=15177025$

White, J. G., Southgate, E., Thomson, J. N., \& Brenner, S. (1986). The structure of the nervous system of the nematode Caenorhabditis elegans. Philos Trans R Soc Lond B Biol Sci, 314(1165), pp. 1-340. doi:10.1098/rstb.1986.0056 Retrieved from https://www.ncbi.nlm.nih.gov/pubmed/22462104

Woodhead, G. J., Mutch, C. A., Olson, E. C., \& Chenn, A. (2006). Cell-autonomous betacatenin signaling regulates cortical precursor proliferation. J Neurosci, 26(48), pp. 12620- 
12630. doi:10.1523/JNEUROSCI.3180-06.2006 Retrieved from http://www.ncbi.nlm.nih.gov/pubmed/17135424

Xue, D., Finney, M., Ruvkun, G., \& Chalfie, M. (1992). Regulation of the mec-3 gene by the C.elegans homeoproteins UNC-86 and MEC-3. EMBO J, 11(13), pp. 4969-4979. Retrieved from https://www.ncbi.nlm.nih.gov/pubmed/1361171

Yu, S., Avery, L., Baude, E., \& Garbers, D. L. (1997). Guanylyl cyclase expression in specific sensory neurons: a new family of chemosensory receptors. Proc Natl Acad Sci US A, 94(7), pp. 3384-3387. doi:10.1073/pnas.94.7.3384 Retrieved from https://www.ncbi.nlm.nih.gov/pubmed/9096403

Zhang, Y., Ma, C., Delohery, T., Nasipak, B., Foat, B. C., Bounoutas, A., .. . Chalfie, M. (2002). Identification of genes expressed in C. elegans touch receptor neurons. Nature, 418(6895), pp. 331-335. doi:10.1038/nature00891 Retrieved from http://www.ncbi.nlm.nih.gov/pubmed/12124626

Zhao, Z., Boyle, T. J., Bao, Z., Murray, J. I., Mericle, B., \& Waterston, R. H. (2008). Comparative analysis of embryonic cell lineage between Caenorhabditis briggsae and Caenorhabditis elegans. Dev Biol, 314(1), pp. 93-99. doi:10.1016/j.ydbio.2007.11.015 Retrieved from https://www.ncbi.nlm.nih.gov/pubmed/18164284 


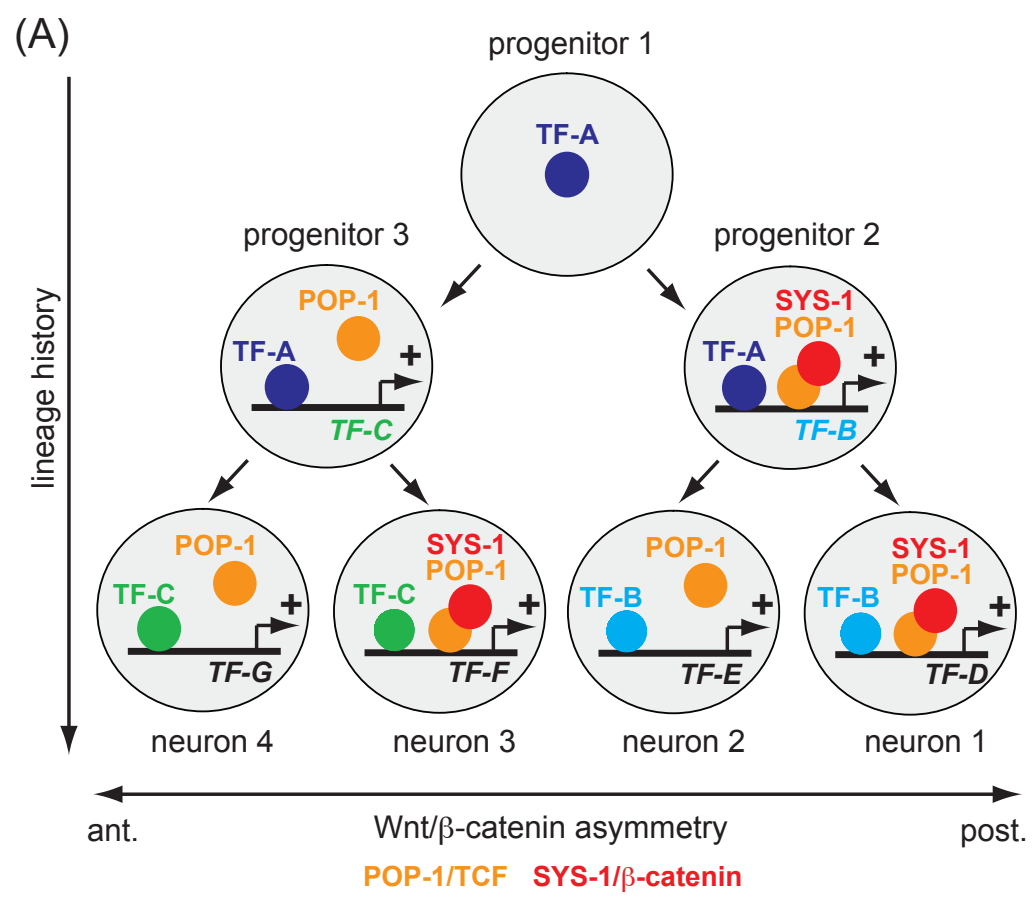

(B)

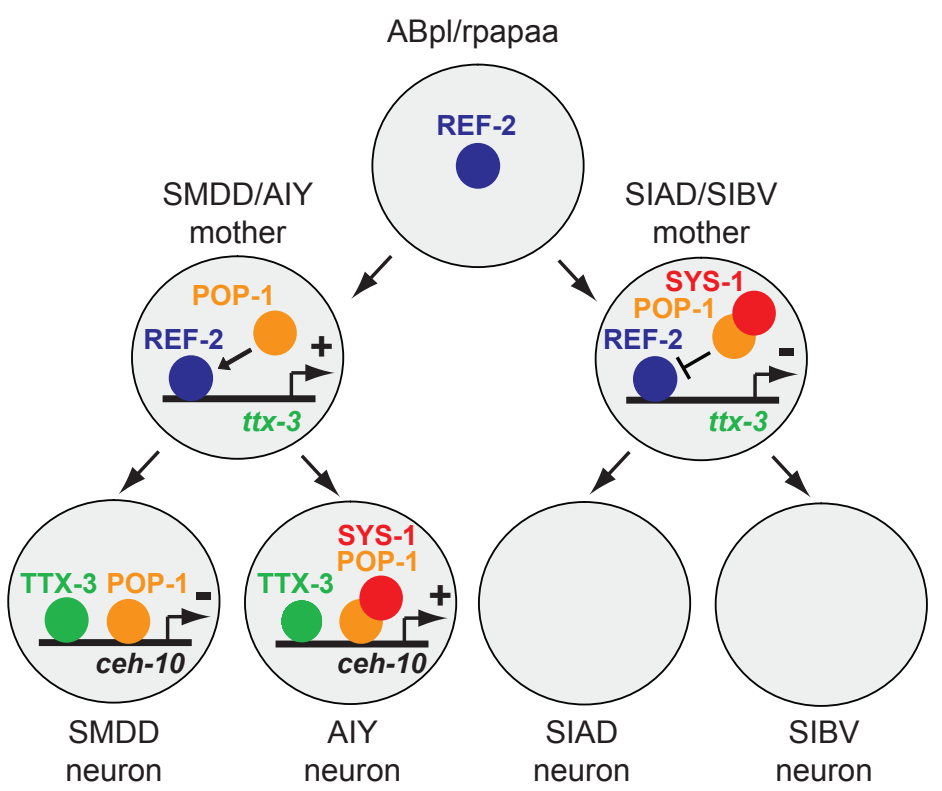




\section{Transient developmental inputs}

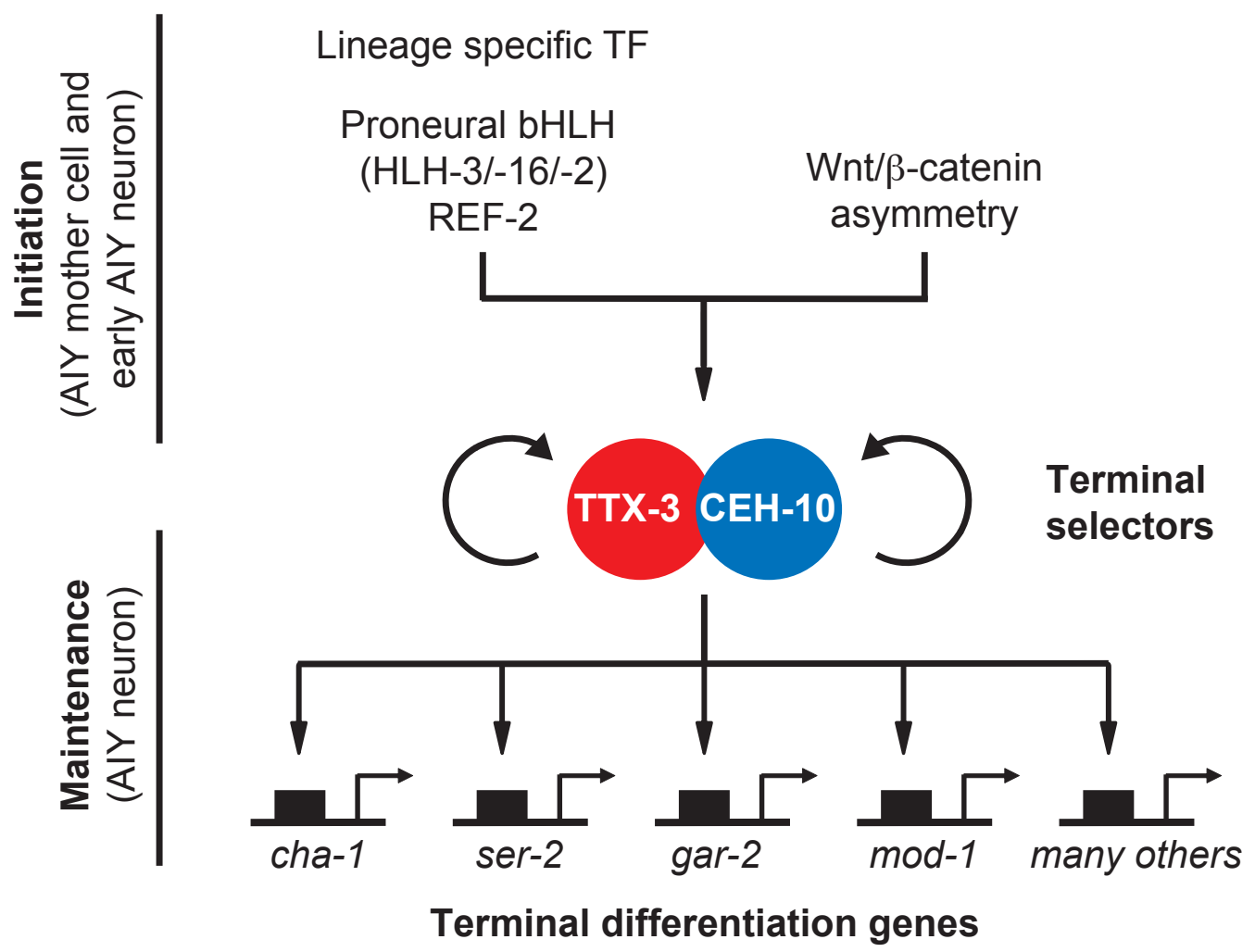


(A)
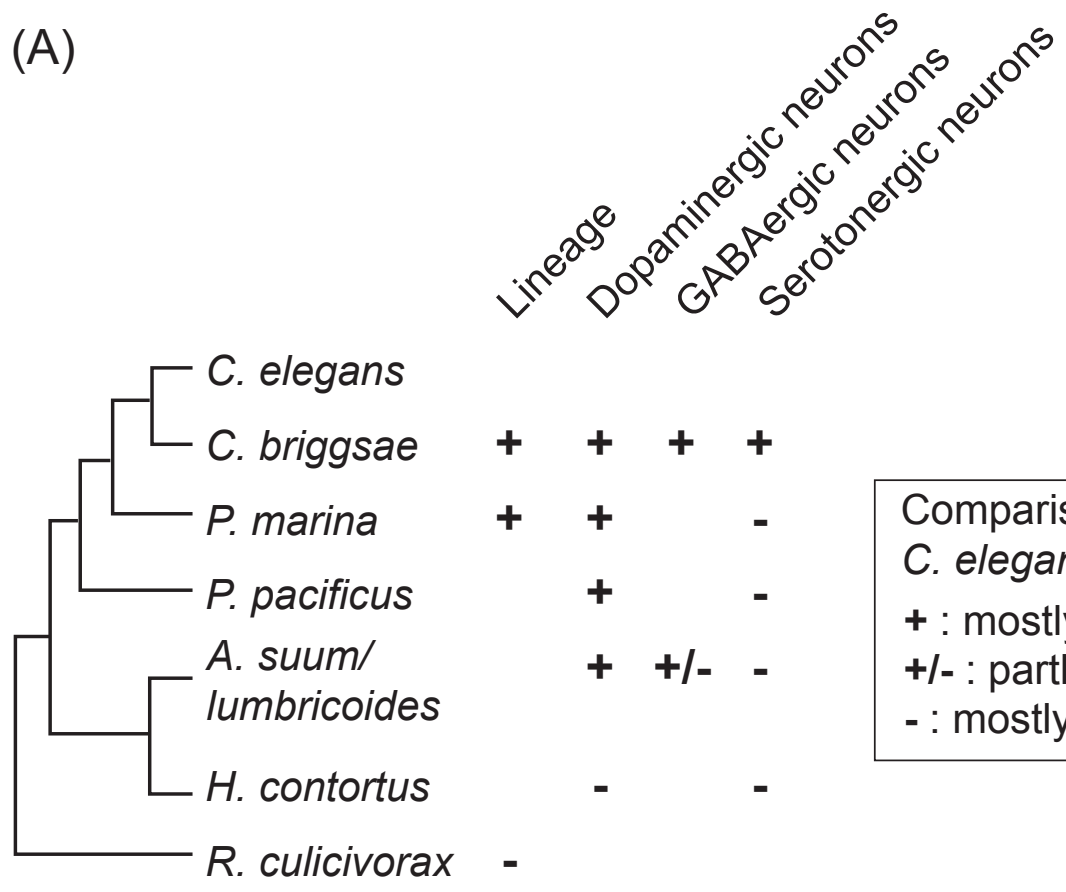

Comparison with

C. elegans :

$+:$ mostly conserved

+/- : partly conserved

- : mostly not conserved
(B)

C. briggsae

C. elegans

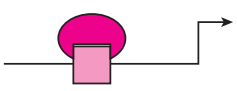

Conservation

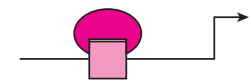

TF/binding site coevolution

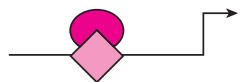

TF change

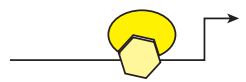

C. briggsae promoter in C. elegans
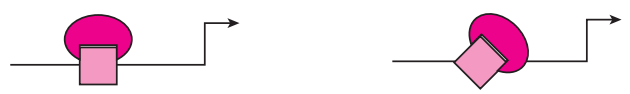

Altered regulation

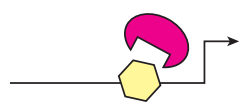

Lost regulation 